\title{
Implementasi Model Pembelajaran Koperatif Tipe STAD untuk Meningkatkan Prestasi Belajar Gerak Dasar Passing Bawah Bola Voly pada Siswa Kelas V SD
}

\section{Ketut Suasa ${ }^{1^{*}}$}

${ }^{1}$ SD Negeri 6 Busungbiu Singaraja, Indonesia

\section{ART ICLE IN F O}

Article history:

Received July 16, 2021

Revised July 25, 2021

Accepted October 20, 2021

Available online November 25, 2021

Kata Kunci:

Kooperatif Tipe STAD, Gerak Dasar

Passing Bawah, Prestasi belajar.

Keywords:

STAD Cooperative Type, Basic Passing Down Movement, Learning achievement

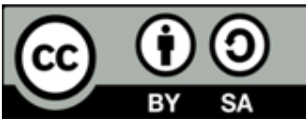

This is an open access article under the CC BY-SA license.

Copyright $(\subseteq 2021$ by Author. Published by Universitas Pendidikan Ganesha.

\begin{abstract}
A B S T R A K
Kemampuan siswa untuk mengaplikasikan keterampilan passing bola voly masih rendah. Hal ini disebabkan oleh kurang tepatnya model pembelajaran dalam mengajar keterampilan teknik dasar passing bola voly, sehingga kurang merangsang minat dan motivasi siswa dalam belajar. Penelitian ini bertujuan untuk meningkatkan prestasi belajar gerak dasar passing bawah melalui implementasi model pembelajaran kooperatif tipe STAD pada siswa kelas V SD. Penelitian ini adalah penelitian tindakan kelas yang melibatkan siswa kelas $\mathrm{V}$ yang berjumlah 8 orang siswa. Objek penelitian ini adalah prestasi belajar gerak dasar passing bawah. Dalam penelitian ini, data prestasi belajar siswa dikumpulkan dengan lembar observasi. Data yang terkumpul dianalisis dengan metode deskriptif. Hasil penelitian ini menunjukkan bahwa prestasi belajar gerak dasar passing bawah dinyatakan meningkat. Hal ini dibuktikan dengan terjadi perbedaan prestasi belajar antara siklus I (jumlah 593, ratarata 74 , daya serap $74 \%$, ketuntasan belajar $50 \%$ ) dan siklus II (jumlah 687 , rata-rata 86 , daya serap $86 \%$, ketuntasan belajar $88 \%$ ). Peningkatan prestasi belajar dari siklus I ke siklus II dapat dilihat dari adanya kenaikan rata-rata daya serap $12 \%$ dan pada ketuntasan belajar mengalami kenaikan sebesar $38 \%$. Jadi, implementasi model pembelajaran kooperatif tipe STAD pada siswa kelas V SD dapat meningkatkan prestasi belajar gerak dasar passing bawah.
\end{abstract}

\section{A BSTRACT}

The low ability of students to apply volleyball passing skills. The lack of precise learning models in teaching basic volleyball skills causes less interest and motivation in learning. This study aims to improve learning achievement of the basic movement of passing down through implementing the STAD type cooperative learning model in fifth-grade elementary school students. This research is a classroom action research involving eight students of class $V$. The object of this research is learning the basic movement of passing down. In this study, student achievement data was collected using observation sheets. The data analysis method was descriptive analysis. The results of this study indicate that the achievement of learning basic movements of passing down is stated to be increasing, it is proven that there is a difference in learning achievement between the first cycle (amount 593, average 74 , absorption $74 \%$, learning completeness $50 \%$ ) and cycle II (amount 687, average -average 86 , absorption capacity $86 \%$, complete learning $88 \%$ ). There was an increase in learning achievement between cycle I and cycle II, showing an average increase in absorption of $12 \%$ and learning completeness an increase of 38\%. Thus, implementing the STAD type cooperative learning model in fifth-grade elementary school students can improve learning achievement of basic downward passing movements.

\section{PENDAHULUAN}

Dalam proses pembelajaran, guru harus memiliki startegi agar siswa dapat belajar secara efektif dan efisien untuk mencapai tujuan yang diharapkan (Mariyana, 2020; Rahmawati et al., 2014). Di dalam proses pembelajaran model pembelajaran mempunyai andil yang cukup besar dalan kegiatan belajar mengajar (Ikhwati et al., 2014; Wahanani, 2016). Ini berarti bahwa tujuan pembelajaran bisa tercapai 
apabila menggunakan model pembelajaran yang tepat dan tidak terpaku terhadap satu jenis model. Pengunaan model pembelajaran dimaksudkan untuk meningkatkan aktivitas belajar anak didik, sehinga siswa tidak merasa sulit untuk untuk mencapai tujuan pembelajaran (Ahyar et al., 2017; Dewi et al., 2019), khususnya pada salah satu keterampilan dalam olahraga yaitu keterampilan passing. Peran guru dalam upaya meningkatkan prestasi belajar ketrampilan passing bola voly sangat bergantung pada kreaktivitasnya dalam memperdayakan seluruh potensi yang ada (Suhdy, M., \& Supriyadi, 2020). Kreaktivitas seorang guru tersebut akan tercermin dalam memilih dan menentukan model pembelajaran (Anggreini \& Dewi, 2020; SisteIswanto et al., 2018). Untuk mewujudkan tujuan tersebut, diperlukan berbagai upaya aktif dari pendidik untuk mewujudkan pembelajaran yang efektif dan efisien. Proses pembelajaran di kelas akan berhasil jika dalam pelaksanaannya guru memahami dengan baik peran, fungsi dan kegunaan mata pelajaran yang diajarnya. Di samping mengetahui peran, fungsi dan kegunaan mata pelajaran, guru juga diharapkan mampu menerapkan berbagai model ajar, sehingga mampu meningkatkan prestasi belajar siswa.

Prestasi belajar adalah hasil atau akibat dari kegiatan belajar.Untuk mengetahui tentang prestasi belajar, perlu dijelaskan tentang hakikat belajar (Muchib, 2018; Syafa'ati et al., 2021). Belajar merupakan suatu proses yang dilakukan seseorang untuk memperoleh suatu perubahan tingkah laku yang baru secara keseluruhan, sebagai hasil pengalaman (Sutarto, 2017). Perubahan itu bersifat kontinyu dan fungsional, terjadi secara sadar, bersifat positif dan aktif, bukan bersifat sementara, bertujuan atau terarah, dan mencakup seluruh aspek tingkah laku yang selanjutnya dinamakan hasil belajar dan hasil belajar tersebut dapat dinyatakan dalam bentuk prestasi belajar (Asrini, 2020; Mahfudi, 2020). Prestasi belajar dalam lembaga pendidikan mempunyai arti strategis jika ditinjau dari kegunaannya, adalah sebegai berikut. (1) Prestasi belajar siswa dapat meramalkan dan memproyeksikan perkembangan kemajuan siswa secara individual maupun kelompok; (2) Sebagai bahan laporan tentang kemajuan siswa yang bersangkutan kepada orang tuanya tentang kemampuannya, di samping sebagai keterangan mengenai diri siswa itu selama mengikuti pendidikan pada suatu lembaga tertentu; (3) Bahan informasi tentang keberhasilan studi seseorang bagi suatu sekolah dimana ia berkedudukan sebagai murid baru pada jenjang atau tingkat pendidikan tertentu; (4) Sebagai bahan masukan bagi bimbingan dan penyuluhun (BP) dengan prestasi yang ada, siswa dapat diberi nasehat agar dapat mengatasi masalahmasalah yang dihadapi, serta dapat mengembangkan adaptasi pribadi; (5) Prestasi belajar sisiwa dapat dijadikan sebagai bahan perbandingan tentang metode dan bahan yang diberikan oleh guru dalam pelaksanaan supervisi; (6) Prestasi belajar siswa dapat dijadikan sebagai bahan untuk menentukan status siswa dalam berbagai mata pelajaran; (7) Keperluan penelitian, teutama mengenai penyelenggaraan pengajaran yang kmeliputi penelitian tentang metode yang digunakan pada waktu mengajar kurikulum yang berlaku dan efisien lulusannya (Hamdu, 2011; Putu et al., 2016).

Kenyataan selama ini model pembelajaran yang digunakan cendrung bersifat tradisional, berpusat pada guru (teacher centered). Siswa melakukan latihan fisik atau latihan keterampilan berdasarkan perintah yang ditentukan oleh guru. Latihan-latihan tersebut hampir tidak pernah dilakukan oleh siswa karena inisiatif sendiri (student centered) (Hazmiwati, 2018). Penggunaan model pembelajaran tersebut sangat bertentangan dengan esensi dari belajar gerak dasar permainan bola voly yang mengutamakan unsur bermain, bergembira, sehingga hanya mengakibatkan kebosanan pada siswa. Kelemahan proses pembelajaran yang terjadi selama ini yang mengakibatkan rendahnya prestasi belajar siswa karena masih rendahnya kemauan guru untuk menerapkan model dan strategi pembelajaran yang aktif dan efektif untuk siswa (Cynthia et al., 2015; Sodik et al., 2019). Masih banyak guru lebih cenderung berperan sebagai penyampai materi ajar dari pada sebagai seorang guru sejati yang seharusnya bertugas sebagai pendidik dan pengajar. Kondisi yang ada tentu banyak berpengaruh terhadap kemauan guru menyiapkan bahan yang lebih baik, termasuk kemauan guru untuk menerapkan metode-metode ajar yang telah didapat di bangku kuliah. Selain itu, guru kurang berkeinginan untuk mengembangkan keterampilan mengajar yang dapat menarik perhatian siswa dan merangsang siswa untuk belajar. Salah satu masalah utama dalam proses pembelajaran gerak dasar passing bola voly pada siswa kelas V SD Negeri 6 busungbiu adalah belum efektifnya pelaksanaan proses pembelajaran. Kondisi kualitas pembelajaran gerak dasar passing bola voly yang masih rendah pada SD Negeri 6 Busungbiu dapat dilihat dari adanya kesenjangan antara hasil yang dicapai oleh siswa dan target ketuntasan belajar yang telah ditetapkan. Selain rendahnya hasil belajar, juga kemampuan siswa untuk mengaplikasikan keterampilan passing bola voly yang sebenarnya juga rendah. Hal ini dapat dilihat dari kecenderungan siswa hanya menunggu intruksi dari guru. Guru hanya terpaku pada model pembelajaran tradisional. Kurang tepatnya model pembelajaran dalam mengajar ketrampilan teknik dasar passing bola voly mengakibatkan kurang merangsang minat dan motivasi sisa dalam belajar. Rendahnya motivasi siswa dalam belajar berakibat rendahnya keterampilan siswa. Apabila kondisi semacam ini berlangsung terus menerus akan bisa mempengaruhi prestasi hasil belajar. 
Melihat kesenjangan antara harapan-harapan yang telah disampaikan dan kenyataan lapangan sangat jauh berbeda. Dalam rangka memperbaiki mutu pendidikan utamanya pada mata pelajaran Penjasorkes sangat perlu kiranya dilakukan perbaikan cara pembelajaran. Salah satunya adalah perbaikan pembelajaran dengan menggunakan teori pembelajaran kooperatif tipe STAD. Penggunaan model/metode ini didasarkan pada pemikiran bahwa semua manusia dilahirkan dengan rasa ingin tahu yang tidak pernah terpuaskanmserta mempunyai alat-alat yang diperlukan untuk memuaskannya. Pembelajaran dengan menerapkan kooperatif tipe STAD merupakan salah satu model, strategi, dan pendekatan pembelajaran khususnya menyangkut keterampilan guru dalam merancang, mengembangkan, dan mengelola sistem pembelajaran, sehingga guru mampu menciptakan suasana pembelajaran yang efektif dan menggairahkan (Agustina, 2015; Marheni et al., 2013; Rando \& Pali, 2021). STAD adalah singkatan dari Student Teams Achievement Division. Model ini didesain untuk tim kecil yang berjumlah 4-5 orang. Setiap tim itu bisa diatur tingkat kemampuan siswanya maupun gendernya (Erly, 2020; Nugroho \& Shodikin, 2018). Guru menyajikan pelajaran, kemudian siswa bekerja bertim dan memastikan agar masing-masing individu dalam tim dapat pekerjaan yang dikerjakan dan masing-masing tim meyakinkan dirinya agar anggotanya dapat menguasai pelajaran yang diberikan oleh gurunya. Pembelajaran kooperatif tipe Students Team Achievement Division (STAD) terdiri dari lima komponen utama yang perlu diperhatikan yaitu tahap penyajian kelas (class presentation), belajar dalam kelompok (team), tes/kuis (quizzes), skor kemajuan individu (individual improvment scores) dan penghargaan kelompok (team recognation) (Ikhwati et al., 2014; Laksono et al., 2016; K. R. Lestari, 2013).

Beberapa penelitian sebelumnya menyatakan bahwa tidak terdapat perbedaan hasil belajar siswa yang diajar dengan metode STAD antara siswa yang mempunyai kemampuan potensi akademik tinggi dan rendah (Primartadi, 2013). Penerapan pembelajaran inkuiri terbimbing yang diperkaya dengan unsurunsur STAD dapat meningkatkan hasil belajar peserta didik (Ahyar et al., 2017). Model pembelajaran kooperatif tipe STAD berpengaruh positif dan signifikan terhadap keterampilan sosial siswa (Budiastana, 2015). Temuan lain juga menyatakan terdapat perbedaan yang signifikan antara siswa yang mengikuti model pembelajaran STAD dan TSTS. Perbedaan signifikan dari penerapan dua model dapat dilihat pada rerata posttest keterampilan sosial dari kedua kelas (D. Lestari \& Setyaningtyas, 2020). Mengkaji dan memahami semua penjelasan tersebut, kooperatif tipe STAD diupayakan dalam pembelajaran sebagai solusi untuk mengatasi masalah rendahnya prestasi belajar siswa kelas V di semester I tahun pelajaran 2018/2019. Tujuan penelitian tindakan kelas ini adalah untuk meningkatkan hasil belajar penjasorkes. Manfaat penelitian ini diharapkan dapat menghilangkan kejenuhan siswa dalam belajar penjasorkes dan dapat menarik minat siswa untuk belajar, sehingga dapat meningkatkan hasil belajar siswa.

\section{METODE}

Penelitian ini menggunakan jenis penelitian tindakan kelas yang berdasarkan pada model penelitian tindakan Kanca (2010:4). Penelitian ini dilaksanakan di SD Negeri 6 Busungbiu dengan alamat Banjar Dinas Kaja, Desa Busungbiu, Kecamatan Busungbiu Kabupaten Buleleng. Penelitian ini dilaksanakan pada semester I tahun pelajaran 2018/2019 selama 4 bulan dari bulan Juli sampai dengan Oktober 2018. subjek penelitian ini adalah siswa kelas V yang berjumlah 8 orang, terdiri dari 4 orang lakilaki dan 3 orang perempuan. Siklus I dimulai dengan perencanaan seperti: (1) membuat RPP yang sesuai dengan sintaks model pembelajaran kooperatif tipe STAD, (2) menyiapkan media, sarana dan prasarana yang diperlukan, (3) menyiapkan lembar observasi siswa. Pada tahap pelaksanaan, semua perencanaan pembelajaran yang telah disusun. Secara garis besar pelaksanaan proses pembelajaran adalah: (1) menyampaikan tujuan pelajaran yang akan dicapai pada kegiatan pembelajaran dan menekankan pentingnya topic yang akan dipelajari dan memotivasi siswa, (2) menyajikan informasi kepada siswa dengan jalan demonstrasi atau lewat bahan bacaan, (3) menjelaskan kepada siswa cara membentuk kelompok belajar dan membantu setiap kelompok agar melakukan transisi secara efisien, (4) membimbing kelompok-kelompok belajar pada saat mereka mengerjakan tugas mereka, (5) mengevaluasi hasil belajar tentang materi materi yang telah dipelajari atau masing-masing kelompok mempresentasikan hasil kerjanya, (6) mencari cara-cara untuk menghargai baik upaya maupun hasil belajar individu dan kelompok.

Obervasi dan evaluasi merupakan suatu cara untuk mengamati atas hasil atau dampak dari tindakan yang dilaksanakan atau ditekankan terhadap siswa. Fungsi observasi atau evaluasi adalah untuk mendokumentasikan implikasi tindakan yang diberikan kepada subjek. Refleksi merupakan suatu upaya mengkaji, melihat, dan mempertimbangkan atas hasil atau dampak dari tindakan berbagai kriteria. Setelah dilakukan evaluasi pembelajaran, kekurangan yang dialami siswa dalam proses pembelajaran, maka dicari solusi pemecahan masalah yang menghambat proses pembelajaran. Metode pengumpulan data dalam penelitian ini adalah metode observasi. Untuk pengumpulan data mengenai hasil belajar siswa, 
digunakan lembar observasi. Penilaian teknik passing bawah dilakukan dengan mengamati tahap-tahap passing bawah yaitu tahap-tahap persiapan, tahap pelaksanaan gerak, dan tahap gerak lanjutan. Penilaian tersebut diambil dari pengamatan pada saat siswa melakukan tes passing bawah selama 60 detik. Instrumen yang dipakai untuk menilai teknik passing bawah bagi siswa disajikan pada Tabel 1.

Tabel 1. Lembar penilaian pengamatan pada teknik passing bawah

\begin{tabular}{|c|c|c|c|c|c|c|}
\hline \multirow[t]{2}{*}{ No } & \multirow[t]{2}{*}{ Teknik Passing Bawah } & \multicolumn{5}{|c|}{ Skor } \\
\hline & & 1 & 2 & 3 & 4 & 5 \\
\hline 1 & Persiapan & & & & & \\
\hline 2 & Pelaksanaan gerak & & & & & \\
\hline 3 & Gerak lanjutan & & & & & \\
\hline & Jumlah Skor & & & & & \\
\hline
\end{tabular}

Skor 1-5 jika memenuhi beberapa diantara masing-masing teknik passing bawah yang telah ditentukan. Skor 1 diperoleh apabila siswa sudah melakukan salah satu teknik dengan baik, skor 2 diperoleh apabila siswa sudah melakukan dua diantara beberapa teknik yang ada dengan baik, skor 3 diperoleh apabila siswa sudah melakukan 3 diantara beberapa teknik yang ada dengan baik, skor 4 diperoleh apabila siswa sudah melakukan 4 diantara beberapa teknik yang ada dengan baik, skor 5 diperoleh apabila siswa sudah melakukan semua (lima) teknik yang ada dengan baik. Berdasarkan teknik penilaian dari passing bawah bola voli di atas, maka peneliti membuat sebuah lembar observasi yang memudahkan untuk menilai siswa ketika diadakan evaluasi oleh guru. Teknik analisis data yang digunakan dalam penelitian tindakan kelas ini adalah teknik analisis deskriptif. Metode analisis deskriptif adalah cara pengolahan data yang dilakukan dengan jalan menerapkan rumus-rumus statistik deskriptif seperti distribusi frekuensi, angka rata-rata (Mean), untuk menggambarkan keadaan suatu objek tertentu sehingga diperoleh kesimpulan umum.

\section{HASIL DAN PEMBAHASAN}

\section{Hasil}

Data yang diperoleh dari hasil kegiatan awal yang dilakukan pada siswa kelas $\mathrm{V}$ pada semester I tahun pelajaran 2018/2019 adalah 5 siswa (62\%) memperoleh nilai di bawah KKM, 3 siswa (38\%) memperoleh nilai rata-rata KKM. Hasil prestasi belajar pada prasiklus diproleh nilai 547 dengan rata-rata 68, daya serap diperoleh $68 \%$ dan ketuntasan belajar $38 \%$. Hasil yang cukup rendah ini tidak terlepas dari kegiatan yang dilakukan guru yang belum profesional. Guru masih mengajar sekehendak hati, belum menyiapkan segala sesuatunya dengan baik, belum melihat dan belum membaca teori-teori para ahli yang benar, masih tradisional dan konvensional. Dengan ketidakberhasilan tersebut, maka guru sebagai praktisi dituntut untuk lebih mampu membuat agar pembelajaran menjadi lebih konstruktivis, mengikuti kemajuan jaman, dan mengajar dengan menggunakan metode / model yang lebih modern dan sesuai kebenaran / logika. Hasil yang diperoleh dari penilaian prestasi belajar Siklus I terhadap kemampuan peserta mempelajari materi-materi dari mata pelajaran Penjasorkes yang sudah dilakukan yaitu dari 8 siswa yang diteliti baru 4 siswa (50\%) yang memperoleh nilai di atas KKM, ada 4 siswa (50\%) masih mendapat penilaian di bawah KKM. Hasil prestasi belajar pada siklus I diproleh nilai 593 dengan rata-rata 74, daya serap diperoleh 74\% dan ketuntasan belajar $50 \%$. Sintesis yang dapat disampaikan adalah 4 siswa tergolong mampu dengan 1 siswa masuk kategori baru mencapai KKM, dan 4 siswa anak yang lain belum berkembang sesuai indikator. Itu artinya dituntut upaya lebih keras di pihak guru untuk mencapai tingkat kemampuan yang dipersyaratkan dalam indikator keberhasilan penelitian

Gambaran kekurangan dan kelebihan dari pelaksanaan tindakan siklus I yang perlu disampaikan. Kekurangannya adalah sebagai beikut. (1) Kemampuan belajar siswa belum maksimal, masih ada banyak siswa yang perkembangannya belum maksimal. Oleh karena itu, dibutuhkan waktu untuk memperoleh kemampuan yang diharapkan secara merata; (2) Alat peraga belum begitu menarik; (3) Siswa baru sampai pada tahap meniru teman-temannya, guru belum mampu mengaktifkan siswa secara maksimal; (4) Media penghubung ingatan anak dalam belajar pada mata pelajaran Penjaskes telah direncanakan belum dapat diupayakan secara maksimal Gambaran kelebihan pelaksanaan tindakan siklus I yang perlu disampaikan adalah sebago berikut. (1) Persiapan pembelajaan telah diupayakan dengan maksimal; (2) Pengelolaan proses pembelajaran untuk menarik perhatian siswa juga sudah diusahakan secara maksimal; (3) Untuk validasi data, guru telah mendiskusikan cara pembelajaran dengan teman sejawat. Hasil pengamatan/pengumpulan data pada siklus II dalam hubungan dengan peningkatan prestasi belajar tidak terdapat siswa memperoleh nilai sama dengan KKM dan sedangkan 8 (100\%) diatas KKM. Artinya bahwa mereka berada pada kategori mampu memenuhi tuntutan yang diinginkan. Perkembangan 
prestasi belajar siswa dalam menerima materi pada mata pelajaran Penjaskes setelah dilakanakan siklus II mengalami peningkatan yang menggembirakan. Dari hasil Hasil prestasi belajar pada siklus I diperoleh nilai 687 dengan rata-rata 86, daya serap diperoleh 74\% dan ketuntasan belajar ada 100\% siswa mencapai di atas nilai rata-rata dan bahkan melebihi KKM. Hal tersebut menggambarkan bahwa kemampuan mereka sudah cukup baik. Dari data yang diperoleh dapat diberikan sintesis bahwa hasil yang dicapai oleh anak-anak sudah memenuhi indikator yang ditargetkan. Dengan demikian, penelitian tidak dilanjutnya ke siklus berikutnya dan dinyatakan berhasil. Penilaian yang dapat dijelaskan bahwa pada Siklus II ini indikator yang dituntut dalam upaya meningkatkan prestasi belajar siswa pada mata pelajaran Penjaskes secara tuntas dapat dicapai. Hasil yang diperoleh pada Siklus II ini menunjukkan bahwa hipotesis yang diajukan sudah dapat dibuktikan, kriteria usulan penelitian sudah terpenuhi, dan masalah yang dirumuskan sudah terjawab dengan baik.

\section{Pembahasan}

Berdasarkan hasil penelitian, model pembelajaran kooperatif tipe STAD dapat meningkatkan prestasi belajar gerak dasar passing bawah bola voly pada siswa kelas V SD. Hal ini terbukti berdasarkan dari analisis pelaksanaan tindakan siklus I dan pelaksanaan siklus II diperoleh nilai rata-rata prestasi belajar siswa pada siklus I yaitu sebesar 74 dan nilai rata-rata prestasi belajar pada siklus II yaitu sebesar 86. Hal ini menunjukkan bahwa masalah/kendala yang terjadi pada siklus I relatif sudah dapat teratasi dengan baik. Selain itu, prestasi belajar meningkat karena siswa melakukan tahapan pembelajaran kooperatif tipe STAD dengan baik, khususnya pada tahapan kerja tim. Bekerja dan berpikir secara kelompok dapat meringankan beban setiap anggota kelompok. Pembelajaran kooperatif memberikan kesadaran pada komponen sekolah akan manfaat akademis dan sosial yang diperoleh siswa dari bekerja sama dan saling membantu. Pembelajaran STAD memberikan kesempatan pada peserta didik untuk berinteraksi lebih intensif dengan teman sebayanya, sehingga lebih mudah dalam menyelesaikan permasalahan (Ahyar et al., 2017; Hadinata et al., 2017). Model pembelajaran kooperatif STAD merupakan strategi alternatif untuk mencapai tujuan pembelajaran antara lain meningatkan kemampuan siswa untuk bekerjasama dengan siswa lain, dan pada saat yang bersamaan dapat meningatkan prestasi akademik siswa (Hazmiwati, 2018).

Selain itu, pembelajaran kooperatif tipe STAD untuk meningatkan prestasi belajar dapat membantu siswa untuk mampu berpendapat sendiri. Siswa belajar dan beraktivitas sendiri untuk memperoleh pengalaman, pengetahuan, pemahaman dan tingah laku lainnya serta mengembangkan ketrampilanya yang bermakna, yaitu kegiatan atau akttivitas belajar siswa merupakan pondasi dan prinsip fundamental untuk mencapai keaktifan dan prestasi belajar yang lebih baik (Kristin, 2016; D. Lestari \& Setyaningtyas, 2020). Prestasi belajar merujuk pada perubahan struktur pengetahuan individu sebagai hasil dari situasi belajar. Prestasi belajar beranekaragaman besarnya, baik yang menyangkut belajar fakta sederhana maupun keterampilan-keterampilan teknis yang bersifat kompleks (Fitroturrohmah et al., 2019; Handayani \& Septhiani, 2021). Hasil penelitian ini membuktikan bahwa melalui pembelajaran kooperatif STAD ada peningkatan dalam beberapa hal. Keaktifan siswa meningkat dalam kegiatan kelompok, dalam mengerjakan tugas-tugas dan berpikir bersama. Hasil belajar siswa pada ranah kognitif, afektif, dan psikomotor, respon terhadap proses pembelajaran juga meningkat. Dari seluruh kegiatan yang diberikan kepada siswa, pembelajaran yang dilaksanakan merupakan hal baru,. Siswa merasa senang mengikuti pelajaran, tugas lebih mudah dikerjakan, termotivasi mengerjakan tugas, merasa siap untuk menjawab pertanyaan, dapat memusatkan perhatian, serta lebih bergairah. Temuan ini diperkuat dengan penelitian sebelumnya yang menyatakan pembelajaran kooperatif STAD untuk meningatkan hasil belajar. Model pembelajaran kooperatif STAD untuk meningatkan prestasi dan keaktifan siswa .(Sunarti \& Rachman, 2018) Penerapan pembelajaran STAD berbantuan media komik efektif ditinjau dari tingkat ketuntasan belajar siswa, aktivitas siswa, aktivitas guru, dan respon siswa (Nugroho \& Shodikin, 2018). Terdapat perbedaan hasil belajar IPA dan self-efficacy siswa yang menggunakan model pembelajaran kooperatif STAD berbantuan mind map dan model pembelajaran langsung (Sari et al., 2018). Jadi, berdasarkan jabaran hasil penelitian dan hasil penelitian sebelumnya dapat diakatakan bahwa model pembelajaran STAD efektif untuk meningkatkan prestasi belajar siswa. Pembelajaran dengan model STAD dapat merangsang siswa untuk berinteraksi dengan baik dan berkerja sama. Hal ini menujukkan bahwa pembelajaran kooperatif STAD dapat membantu siswa untuk meningkatkan prestasi belajar gerak dasar passing bawah bola voly pada siswa. Hal ini mendapat respon positif dari siswa. Dengan pembelajaran kooperatif STAD, prestasi belajar siswa meningkat dan siswa lebih mudah belajar karena adanya bimbingan dari teman sekelompoknya melalui diskusi. 


\section{SIMPULAN}

Model pembelajaran kooperatif tipe STAD dapat meningkatkan prestasi belajar gerak dasar passing bawah bola voly pada siswa. Hal ini ditunjukkan dengan terjadinya peningkatan prestasi belajar pada setiap siklus. Direkomendasikan kepada pendidik untuk menggunakan model STAD karena sudah terbukti dari hasil penelitian yang dapat meningkatakan prestasi belajar siswa.

\section{DAFTAR RUJUKAN}

Agustina, R. L. (2015). Upaya Meningkatkan Hasil Belajar IPA Siswa Kelas IV Menggunakan Model STAD dan NHT. Journal of Educational Science and Technology (EST), 1 (3). https://doi.org/10.26858/est.v1i3.1801.

Ahyar, L. M., Ibnu, S., \& Affandy, D. (2017). Penerapan Stad dalam Pembelajaran Inkuiri Terbimbing Dan Pengaruhnya terhadap Hasil Belajar Peserta Didik. J-PEK (Jurnal Pembelajaran Kimia), 2(1), 2130. https://doi.org/10.17977/um026v2i12017p021.

Anggreini, R. K., \& Dewi, N. R. (2020). Development of Ludo-Science Media with a Somatic Auditory Visual Intellectual (SAVI) Approach to Train the Activeness and Conceptual Understanding. Jurnal Penelitian Dan Pembelajaran IPA, 6(2), 241-267. https://doi.org/10.30870/jppi.v6i2.8677.

Asrini, N. W. (2020). Meningkatkan Prestasi Belajar IPS Melalui Penggunaan Model Pembelajaran Pair Check. Journal of Education Action Research, 4(3), 338-344. https://doi.org/10.23887/jear.v4i3.27402.

Budiastana, P. (2015). Pengaruh Penerapan Model Pembelajaran Kooperatif Tipe STAD terhadap Kemampuan Kognisi dan Keterampilan Sosial pada Siswa Sekolah Menengah Pertama. Ekuitas: Jurnal Pendidikan Ekonomi, 1(1). https://doi.org/10.23887/ekuitas.v3i1.12782.

Cynthia, L. C., Martono, T., \& Indriayu, M. (2015). Pengaruh Fasilitas Belajar dan Motivasi Belajar terhadap Prestasi Belajar Mata Pelajaran Ekonomi Siswa Kelas XI IIS di SMA Negeri 5 Surakarta Tahun Ajaran 2015/2016. Jurnal Pendidikan Bisnis Dan Ekonomi, 1(2), 1-20. http://jurnal.fkip.uns.ac.id/index.php/ptn/article/view/7397/5169.

Dewi, A. C., Hapidin, \& Akbar, Z. (2019). Pengaruh Model Pembelajaran dan Kemampuan Berpikir Kritis terhadap Pemahaman Sains Fisik. Jurnal Obsesi : Jurnal Pendidikan Anak Usia Dini, 3(1), 18. https://doi.org/10.31004/obsesi.v3i1.136.

Erly. (2020). Model Cooperative Learning Tipe Student Teams Achievement Divisions (STAD): Dampaknya terhadap Motivasi Belajar Siswa. Indonesian Journal of Science and Mathematics Education, 3(1), 1-8. https://doi.org/10.24042/ijsme.v3i1.5960.

Fitroturrohmah, M., Purwadi, \& Azizah, M. (2019). Hubungan Peran Orang Tua dengan Prestasi Belajar Siswa Kelas Tinggi SDN Kedung 01 Jepara. Journal of Primary and Children's Education 2, 2(2), 25 30. http://jurnal.unw.ac.id/index.php/janacitta.

Hadinata, L. W., Utaya, S., \& Setyosari, P. (2017). Pengaruh Pembelajaran Student Team Achievement Division dan Diskusi terhadap Hasil Belajar IPA Kelas IV SD. Jurnal Pendidikan: Teori, Penelitian, Dan Pengembangan, 2(7), 979-985. https://doi.org/10.17977/jptpp.v2i7.9693.

Hamdu, G. dan L. A. (2011). Pengaruh Motivasi Belajar Siswa terhadap Prestasi Belajar IPA di Sekolah Dasar. Jurnal Penelitian Pendidikan, 12(1), 81-86.

Handayani, D., \& Septhiani, S. (2021). Pengaruh Kecerdasan Emosional Aspek Kesadaran Diri terhadap Prestasi Belajar Matematika. Jurnal Cendekia: Jurnal Pendidikan Matematika, 05(02), 1352-1358. https://doi.org/10.31004/cendekia.v5i2.585.

Hazmiwati, H. (2018). Penerapan Model Pembelajaran Kooperatif Tipe Stad untuk Meningkatkan Hasil Belajar IPA Siswa Kelas II Sekolah Dasar. Primary: Jurnal Pendidikan Guru Sekolah Dasar, 7(1), 178. https://doi.org/10.33578/jpfkip.v7i1.5359.

Ikhwati, H., Sudarmin, S., \& Parmin, P. (2014). Pengembangan Media Flashcard IPA Terpadu dalam Pembelajaran Model Kooperatif Tipe Students Teams Achievement Divisions (STAD) Tema Polusi Udara. Unnes Science Education Journal, 3(2). https://doi.org/10.15294/USEJ.V3I2.3344.

Kristin, F. (2016). Efektivitas Model Pembelajaran Kooperatif Tipe STAD Ditinjau dari Hasil Belajar IPS Siswa Kelas 4 SD. Scholaria: Jurnal Pendidikan Dan Kebudayaan, 6(2), 74. https://doi.org/10.24246/j.scholaria.2016.v6.i2.p74-79.

Laksono, Y. S., Ariyanti, G., \& Santoso, F. G. I. (2016). Hubungan Minat Belajar Siswa terhadap Prestasi Belajar Matematika Siswa dalam Pembelajaran Kooperatif Tipe Stad Menggunakan Komik. Jurnal Edukasi Matematika Dan Sains, 1(2), 60-64. https://doi.org/10.25273/jems.v1i2.143.

Lestari, D., \& Setyaningtyas, E. W. (2020). Perbedaan Pengaruh Model Pembelajaran STAD dengan TSTS terhadap Keterampilan Sosial Muatan IPS. Didaktika Tauhidi: Jurnal Pendidikan Guru Sekolah Dasar, 7(1), 55. https://doi.org/10.30997/dt.v7i1.2659. 
Lestari, K. R. (2013). Model Pembelajaran Koperatif STAD untuk Meningkatkan Aktivitas dan Hasil Belajar Senam Lantai. Jurnal Pendidikan Jasmani, Olahraga, Dan Kesehatan Undiksha, 1(1), 1-10. https://ejournal.undiksha.ac.id/index.php/JJP/article/view/333.

Mahfudi, H. N. (2020). Hubungan Peran Orang Tua terhadap Prestasi Belajar Siswa Kelas V SDN Legokulon 2. Education and Learning of Elementary School, 1(1), 1-9. http://ejournal.stkipmodernngawi.ac.id/index.php/ELES/article/view/177.

Marheni, Sujana, \& Putra, S. (2013). Penerapan Model Pembelajaran Kooperatif tipe STAD untuk Meningkatkan Keaktifan dan Hasil Belajar IPS Kelas V SD no. 8 Padangsambian Denpasar. MIMBAR PGSD, 1(1), 1-10. https://doi.org/10.23887/jjpgsd.v1i1.1438.

Mariyana, D. (2020). Peningkatan Prestasi Belajar IPA tentang Tata Surya melalui Penerapan Model Pembelajaran Kooperatif Tipe TAI (Team Assisted Individualization) bagi Peserta Didik Kelas VI Sekolah Dasar. Social, Humanities, and Educational Studies (SHEs): Conference Series, 3(4), 787792. https://doi.org/10.20961/shes.v3i4.54403.

Muchib, M. (2018). Penerapan Model PBL dengan Video untuk Meningkatkan Minat dan Prestasi Belajar Bahasa Indonesia. Wiyata Dharma: Jurnal Penelitian Dan Evaluasi Pendidikan, 6(1), 25. https://doi.org/10.30738/wd.v6i1.3356.

Nugroho, S., \& Shodikin, A. (2018). Efektivitas Pembelajaran Student Teams Achievement Division (STAD) Berbantuan Komik pada Siswa SD. JMPM: Jurnal Matematika Dan Pendidikan Matematika, 3(1), 22-32. https://doi.org/10.26594/jmpm.v3i1.1067.

Primartadi, A. (2013). Pengaruh Metode Student Teams-Achievement Division (STAD) dan Mroblem Based Learning terhadap Hasil Belajar Ditinjau dari Potensi Akademik Siswa SMK Otomotif. Jurnal Pendidikan Vokasi, 2(2), 143-153. https://doi.org/10.21831/jpv.v2i2.1024.

Putu, N., Sp, S., Japa, I. G. N., \& Arini, N. W. (2016). Hubungan antara Prestasi Belajar dan Peranan Orang Tua serta Interaksi Teman Sebaya Mata Pelajaran PKN. E-Journal PGSD Universitas Pendidikan Ganesha, 4(1), 1-11. https://doi.org/10.23887/jjpgsd.v4i1.7465.

Rahmawati, F., Sudarma, I. K., \& Sulastri, M. (2014). Hubungan antara Pola Asuh Orang Tua dan Kebiasaan Belajar terhadap Prestasi Belajar Siswa SD Kelas IV Semester Genap di Kecamatan MelayaJembrana. Jurnal: Mimbar PGSD Undiksha, 2(1), 1-11. https://doi.org/10.23887/jjpgsd.v2i1.2444.

Rando, A. R., \& Pali, A. (2021). Efektivitas Model Pembelajaran Kooperatif Tipe STAD dalam Mengembangkan Keterampilan Sosial Peserta Didik Di SD INPRES Ende 14. Mimbar PGSD, 9(2). https://doi.org/10.23887/jjpgsd.v9i2.32983.

Sari, N. P. I. K., Arnyana, I. B. P., \& Mardana, I. B. P. (2018). Pengaruh Model Pembelajaran Kooperatif STAD Berbantuan Mind Map terhadap Hasil Belajar IPA dan Self Efficacy Siswa Kelas VIII SMP. Jurnal Imiah Pendidikan Dan Pembelajaran, 2(2), 229-236. https://doi.org/10.23887/jipp.v2i2.15607.

SisteIswanto, E., Sumiharsono, R., \& Hidayat, S. (2018). Pengaruh Penggunaan Media Pembelajaran Berbasis Powerpoint dan Buku Teks terhadap Hasil Belajar Ilmu Pengetahuan Alam (IPA) Materi Tata Surya Siswa Kelas VI Semester Ganjil Tahun Pelajaran 2018-2019 di MI Negeri 2 Jember. Journal of Education Tech, 1(2), 7-20. https://doi.org/10.31537/jeti.v1i2.172.

Sodik, M., Sahal, Y. F. D., \& Herlina, N. H. (2019). Pengaruh Kinerja Guru dalam Pelaksanaan Pembelajaran terhadap Prestasi Belajar Siswa pada Mata Pelajaran Alquran Hadis. Jurnal Penelitian Pendidikan Islam, 7(1), 97. https://doi.org/10.36667/jppi.v7i1.359.

Suhdy, M., \& Supriyadi, M. (2020). Penerapan Pendekatan Tutorial pada Pembelajaran Servis Atas Bola Voli di Smp Negeri 13 Lubuklinggau. 4, 69-77.

Sunarti, S., \& Rachman, D. (2018). The Effectiveness of Flip Classroom with Student Teams-Achievement Divisions (STAD) Method to Teach Reading Viewed from Students' English Learning Interest. Script Journal: Journal of Linguistic and English Teaching, 3(2), 183. https://doi.org/10.24903/sj.v3i2.246.

Sutarto, S. (2017). Dampak Pengiring Pembelajaran Pendekatan Saintifik untuk Mengembangan Sikap Spiritual dan Sosial Siswa. Jurnal Cakrawala Pendidikan, 36(1), 44-56. https://doi.org/10.21831/cp.v36i1.12792.

Syafa'ati, J. S. N., Sucipto, \& Roysa, M. (2021). Analisis Prestasi Belajar Siswa pada Pembelajaran Daring di Masa Pandemi COVID-19. Jurnal Educatio, 7(1), 122-128. https://doi.org/10.31949/educatio.v7i1.882.

Wahanani, S. (2016). Penerapan Pendekatan Cooperative Learning STAD untuk Meningkatkan Hasil Belajar PKn pada Siswa Sekolah Dasar. Jurnal Tarbawi, 13(2), 47-60. https://doi.org/10.34001/tarbawi.v13i2.592. 